\title{
Effect of different freezing rates during cryopreservation of rat mesenchymal stem cells using combinations of hydroxyethyl starch and dimethylsulfoxide
}

Yahaira Naaldijk, Marek Staude, Viktoriya Fedorova and Alexandra Stolzing*

\begin{abstract}
Background: Mesenchymal stem cells (MSCs) are increasingly used as therapeutic agents as well as research tools in regenerative medicine. Development of technologies which allow storing and banking of MSC with minimal loss of cell viability, differentiation capacity, and function is required for clinical and research applications. Cryopreservation is the most effective way to preserve cells long term, but it involves potentially cytotoxic compounds and processing steps. Here, we investigate the effect of decreasing dimethyl sulfoxide (DMSO) concentrations in cryosolution by substituting with hydroxyethyl starch (HES) of different molecular weights using different freezing rates. Post-thaw viability, phenotype and osteogenic differentiation capacity of MSCs were analysed.
\end{abstract}

Results: The study confirms that, for rat MSC, cryopreservation effects need to be assessed some time after, rather than immediately after thawing. MSCs cryopreserved with HES maintain their characteristic cell surface marker expression as well as the osteogenic, adipogenic and chondrogenic differentiation potential. HES alone does not provide sufficient cryoprotection for rat MSCs, but provides good cryoprotection in combination with DMSO, permitting the DMSO content to be reduced to $5 \%$. There are indications that such a combination would seem useful not just for the clinical disadvantages of DMSO but also based on a tendency for reduced osteogenic differentiation capacity of rat MSC cryopreserved with high DMSO concentration. HES molecular weight appears to play only a minor role in its capacity to act as a cryopreservation solution for MSC. The use of a 'straight freeze' protocol is no less effective in maintaining post-thaw viability of MSC compared to controlled rate freezing methods.

Conclusion: A 5\% DMSO / 5\% HES solution cryopreservation solution using a 'straight freeze' approach can be recommended for rat MSC.

Keywords: Mesenchymal stem cells, Cryopreservation, Controlled rate freezing, Hydroxyethyl starch

\section{Background}

Mesenchymal stem cells (MSC) provide a useful tool for regenerative medicine due to their differentiation capacity, immunosuppressive properties, secretome profile and migratory ability $[1,2]$.

MSC represent a valuable source for research and clinical applications due to their ability to produce a range of different cell types including osteoblasts, adipocytes,

\footnotetext{
* Correspondence: Alexandra.Stolzing@izi.fraunhofer.de

Fraunhofer Institute for Cell Therapy and Immunology, Perlickstrasse 1, Leipzig 04103, Germany
}

chondrocytes and myoblasts [3-6]. Effective cryopreservation MSCs offers an opportunity to advance the potential use and implementation of these cells into clinical applications.

Cryopreservation itself can affect differentiation capacity of stem cells $[7,8]$. The loss of a variety of pluripotency markers has been associated with cryopreservation $[9,10]$ but the precise reasons for these changes remain to be explored.

Many studies on the cryopreservation of MSCs were carried out using slow-rate cooling methods $[11,12]$ 
which is often considered a superior method of preservation $[13,14]$. However, limited evidence exists whether the freezing rate in fact affects stem cell growth and differentiation potential. Both 'slow' [15-19] and 'fast' $[20,21]$ freezing protocols have reported 'success' as far as maintaining similar phenotypes, cell surface markers and growth rates in comparison with unfrozen MSC.

Several groups have investigated MSC (from different sources) cryopreservation using 10\% DMSO and slow freezing protocols. In these studies, the cryopreserved MSC maintained similar phenotypes, cell surface markers and growth rates in comparison with fresh cells $[19,22,23]$. In addition fast freezing protocols (vitrification) have been investigated with MSC, showing normal proliferation, phenotype and differentiation $[20,21]$.

To facilitate freezing, a cryoprotectant is usually added. An ideal cryoprotection solution should be nontoxic for cells and patients, nonantigenic, chemically inert, provide high survival rate after thawing and allow transplantation without washing. The most commonly used cryoprotector, DMSO, shows cytotoxicity $[7,8]$. Clinically, DMSO can cause leukoencephalopathy [24], epileptic seizures [25] or elevated lactate dehydrogenase levels [26] after transplantation of DMSO-preserved human bone marrow cells. DMSO is thought to interact with the metabolism and membrane of cells, resulting in cell damage [27]. Nonetheless, DMSO is widely seen as indispensible at least as a component of a cryoprotectants solution.

Additions to DMSO include methycellulose [28], PVP [29], trehalose [30] or others and these components are not investigated here.

Another substitution compound for DMSO in cryoprotection is Hydroxylethyl Starch (HES) which is used in the clinical setting as a plasma volume expander [31-35]. A number of different cell types have been cryopreserved using HES [36-38] with red blood cells being routinely cryopreserved in cryoprotective solutions containing HES $[33,39,40]$. Bone marrow cells from human and other animal species have also been cryopreserved in HES-containing solutions [41-43].

Physical and chemical properties such as solubility, molecular stability as well as rate of hydrolysis and metabolism depend on molecular weight (MW) and degree of substitution of HES molecules. HESs with lower MW have higher solubility and slower breakdown rates $[41,43]$. A variety of different HESs with different MW are currently clinically approved and commercially available.

In this study we attempt an initial comparison of two independent factors: freezing rates and cryopreservation solutions. We analysed their effect on viability, growth characteristics and differentiation potential of rat MSCs after cryopreservation.

\section{Methods}

\section{Isolation of mesenchymal stem cells}

The rat (Sprague Dawley, 2-3 month old, male) was killed by controlled inhalation of $\mathrm{CO}_{2}$. The hind legs were removed, the soft tissue removed and the separated bones (tibia, femur) were stored in PBS. The bones were centrifuged at $1000 \mathrm{rpm}$ for $5 \mathrm{~min}$ and bone marrow was resuspended in $1 \mathrm{ml}$ DMEM.

\section{Cell culture}

Cells obtained from each animal were distributed into two T75 flasks and incubated at $37^{\circ} \mathrm{C}$. The first medium change was done after 5 days and afterwards every 2 to 3 days. For the experiments we used MSCs from passage 1 to passage 3 .

Rat MSCs were cultured in 1x Dulbecco's modified Eagle's medium (DMEM, $1 \mathrm{~g} / \mathrm{L}$ D-Glucose, Invitrogen) containing $10 \%$ fetal bovine serum (FBS, Hyclone) and $1 \%$ penicillin/streptomycin (pen/strep, Invitrogen).

\section{Cryopreservation}

MSCs were frozen when they reached $80 \%$ confluency. Prior to freezing, cell number was determined by trypan blue staining using a Neubauer hemocytometer. $10^{5}$ cells were added to each cryogenic vial ( $2 \mathrm{ml}$ Nalgene). MSC were centrifuged for $5 \mathrm{~min}(1000 \mathrm{rpm}$ at room temperature) to pellet the cells, media was removed and CPA was slowly $(10 \mathrm{sec})$ added with a pipette and the cells were carefully re-suspended. CPA were containing $500 \mu \mathrm{l}$ of prepared cryoprotectant consisting of hydroxyethyl starches of different mean molecular weights $(\mathrm{MW}=109,209$, 309, 409, 509, $609 \mathrm{kDa}$ - Serumwerk, Bernburg) and/or DMSO (Sigma-Aldrich)). Cryogenic vials were kept on ice until samples were frozen applying the different freezing protocols (Table 1) using a rate controlled freezing system (Thermo Scientific) where indicated Model 7452 Series). Protocols used on this study were modified or newly designed based on published protocols [35,44-46]. The chamber of the freezing system was pre-cooled to $4^{\circ} \mathrm{C}$ before each experiment. The samples were stored at $-134^{\circ} \mathrm{C}$ in the vapor phase segment of a liquid nitrogen tank for at least $24 \mathrm{~h}$. Samples were thawed at $37^{\circ} \mathrm{C}$ in a water bath and $10^{4}$ cells were seeded per well in triplicates into pre-warmed culture medium. Fresh unfrozen MSC were seeded as a control.

\section{MTT assay}

The MTT assay was performed 3 days after thawing. Each well was filled with $500 \mu \mathrm{l}$ of media containing of MTT-reagent, consisting of $5 \mathrm{mg} / \mathrm{ml} \mathrm{MTT} \mathrm{(Carl} \mathrm{Roth)}$ in PBS. After incubation for $4 \mathrm{~h}$ at $37^{\circ} \mathrm{C}$, medium was 
Table 1 Freezing protocols used

\begin{tabular}{|c|c|c|c|}
\hline Protocol & Description & Duration [min] & References \\
\hline \multirow[t]{2}{*}{1} & $0,3^{\circ} \mathrm{C} / \mathrm{min}$ to $-100^{\circ} \mathrm{C}$ & 347 & \\
\hline & Store in vapour phase at $-134^{\circ} \mathrm{C}$ & & {$[47]^{*}$} \\
\hline \multirow[t]{2}{*}{2} & $1^{\circ} \mathrm{C} / \mathrm{min}$ to $-80^{\circ} \mathrm{C}$ & 84 & {$[46-50]$} \\
\hline & Store in vapour phase at $-134^{\circ} \mathrm{C}$ & & \\
\hline \multirow[t]{3}{*}{3} & $1^{\circ} \mathrm{C} / \mathrm{min}$ to $-30^{\circ} \mathrm{C}$ & 44 & \\
\hline & $5^{\circ} \mathrm{C} / \mathrm{min}$ to $-80^{\circ} \mathrm{C}$ & & {$[44,51]^{*}$} \\
\hline & xStore in vapour phase at $-134^{\circ} \mathrm{C}$ & & \\
\hline \multirow[t]{5}{*}{4} & $1^{\circ} \mathrm{C} / \mathrm{min}$ to $-20^{\circ} \mathrm{C}$ & 34 & \\
\hline & $5^{\circ} \mathrm{C} / \mathrm{min}$ to $-40^{\circ} \mathrm{C}$ & & \\
\hline & $10^{\circ} \mathrm{C} / \mathrm{min}$ to $-80^{\circ} \mathrm{C}$ & & Designed \\
\hline & $20^{\circ} \mathrm{C} / \mathrm{min}$ to $-100^{\circ} \mathrm{C}$ & & \\
\hline & Store in vapour phase at $-134^{\circ} \mathrm{C}$ & & \\
\hline \multirow[t]{4}{*}{5} & $1^{\circ} \mathrm{C} / \mathrm{min}$ to $-6^{\circ} \mathrm{C}$ & 26 & \\
\hline & $25^{\circ} \mathrm{C} / \mathrm{min}$ to $-50^{\circ} \mathrm{C}$ & & Designed \\
\hline & $10^{\circ} \mathrm{C} /$ min to $-90^{\circ} \mathrm{C}$ & & \\
\hline & Store in vapour phase at $-134^{\circ} \mathrm{C}$ & & \\
\hline 6 & Directly into the vapour phase & 0 & \\
\hline \multirow[t]{2}{*}{7} & $99^{\circ} \mathrm{C} / \mathrm{min}$ to $-100^{\circ} \mathrm{C}$ & 2 & \\
\hline & Store in vapour phase at $-134^{\circ} \mathrm{C}$ & & {$[35,52]^{*}$} \\
\hline
\end{tabular}

* Modified.

removed and $500 \mu \mathrm{l}$ stop-solution (10\% SDS (Merck) and $50 \%$ dimethylformamide, (VWR International)) was added. The cells were incubated overnight at $37^{\circ} \mathrm{C}$ and absorbance was measured using a microplate reader (TECAN) at $550 \mathrm{~nm}$ and $630 \mathrm{~nm}$ as reference wavelength.

\section{Osteogenic differentiation}

The day after thawing medium was changed to osteoinductive medium (low Glucose DMEM; 10\% FBS; 1\% pen/strep; $10 \mathrm{~nm}$ dexamethasone, (Sigma-Aldrich); $50 \mu \mathrm{g} / \mathrm{ml}$ ascorbic acid 2-phosphate, (Sigma-Aldrich)). Differentiation media was changed every 2 days for a period of 14 days. For qualitative analysis of osteogenic differentiation, cells were fixed in $70 \%$ ethanol for $15 \mathrm{~min}$ and washed once with ddH2O.

After washing, cells were stained with ALP buffer $\mathrm{pH}$ $8.5(0.2 \mathrm{M}$ Tris, $1 \mathrm{mg} / \mathrm{ml}$ fast red, Sigma and $50 \mu \mathrm{g} / \mathrm{ml}$ naphtol phosphate AS-BI, Sigma) for $1 \mathrm{hr}$.

\section{Adipogenic differentiation}

Adipogenic medium (10\% FBS; $1 \%$ pen/strep, $10 \%$ insulin-transferrin-selenium supplement, (Sigma-Aldrich) $10^{-8} \mathrm{M}$ dexamethasone (Sigma-Aldrich); $0.5 \mathrm{mM}$ isobutylmethylxanthine, Sigma-Aldrich; $100 \mu \mathrm{M}$ indomethacin, Sigma-Aldrich) was added the day after thawing. The media was changed every 2 days. After 14 days cell phenotype was analyzed by Oil Red O (Sigma-Aldrich) staining.

\section{Chondrogenic differentiation}

Chondrogenic media (10\% FBS; $1 \%$ pen/strep 1\% insulintransferrin-selenium supplement (Sigma-Aldrich), 10-7 M dexamethasone (Sigma-Aldrich), $150 \mu \mathrm{M}$ ascorbic-2phosphate (Sigma-Aldrich), $20 \mu \mathrm{M}$ linoic acid (SigmaAldrich) and $0.1 \mathrm{ng} / \mathrm{ml}$ TGF- $\beta$ (Oncogenic Sciences) was added after thawing. After 2 weeks, cells were stained with Alcian Blue (Sigma-Aldrich).

\section{Quantitative alkaline phosphatase (ALP) assay}

After 14 days of differentiation, the 24 well-plates were washed and fixed with ice-cold $70 \%$ ethanol for $20 \mathrm{~min}$. Ethanol was removed, the plates washed and incubated with $1 \mathrm{ml}$ of p-nitrophenylphosphate $(1 \mathrm{mg} / \mathrm{ml}$, Calbiochem) in TRIS ( $\mathrm{pH}$ 8.0). Cells were incubated for $1 \mathrm{~h}$ at RT and absorbance measured at $405 \mathrm{~nm}$ using a microplate reader (TECAN). Subsequently, the 24 well-plates were rinsed with $\mathrm{ddH}_{2} \mathrm{O}$ and washed with $10 \mathrm{~mm}$ borate buffer ( $\mathrm{pH}$ 8.5, Sigma-Aldrich). $500 \mu \mathrm{l}$ methylene blue (1 $\mathrm{mg} / \mathrm{ml}$, Sigma-Aldrich) in $10 \mathrm{~mm}$ borate buffer was added to each well. After $30 \mathrm{~min}$ incubation at RT the plates were washed with $10 \mathrm{~mm}$ borate buffer and $500 \mu \mathrm{l} 1 \%$ hydrochloric acid (VWR International) was used for dye elution. Plates were incubated for $30 \mathrm{~min}$ at $\mathrm{RT}$ and absorbance was measured at $650 \mathrm{~nm}$ using a microplate reader (TECAN).

\section{Phenotyping of mesenchymal stem cells}

Cells were incubated with CD90 (1:50, Abcam), CD45 (1:100, AbD Serotec), CD11b (1:100, Abcam), and CD44 (1:50, Millipore) for $1 \mathrm{~h}$ at $4^{\circ} \mathrm{C}$, washed and incubated with Cy2 (1:750, Jackson ImmunoResearch) for $45 \mathrm{~min}$ at $4{ }^{\circ} \mathrm{C}$. Cells were washed again and analyzed using the Cytomics FC500 flow cytometer and CXP Analysis 2.1 software (Beckman Coulter).

\section{Cell morphology}

Morphology of the cells was analyzed 3 days after thawing by light microscopy. Pictures were taken at $10 x$ magnification.

\section{Statistics}

All experiments were repeated at least three times. Statistical analysis was performed using ANOVA followed by Turkey test, with $\mathrm{p}<0.05$ considered an indicator of robustness (although not of absolute statistical significance as the number of experiments was too low).

\section{Results}

Rat MSCs were cryopreserved in vials using seven different freezing protocols (Table 1). Different concentrations of DMSO and HES alone or in mixture were tested. 


\section{Verification of consistent nucleation}

Some studies (in the 80's) [53,54] have stressed the importance of capturing a consistent ice nucleation point. While in our experiments (in keeping with many machine-based freezing practices in tissue engineering) nucleation was not initiated 'manually', we can show that nucleation occurs consistently as indicated by a characteristic [55] 'heat release' spike (Additional file 1 Figure S4).

\section{Post-thaw phenotyping}

CD90, CD44, CD45 and CD11b expression were measured in samples cryopreserved using protocol 1 and 7 , in $90 \%$ DMEM and three different cryosolutions: $10 \%$ DMSO, 10\% HES 450 and 5\% DMSO/5\% HES 450. CDs were measured directly after thawing and 3 days later and compared to non-cryopreserved cells (Figure 1). As expected, both MSCs after cryopreservation and non-cryopreserved MSCs have low expression of hematopoietic stem cell markers CD45 and CD11b and high expression of mesenchymal-associated marker CD90 and CD44 [21,56,57]. No differences in CD expression were observed between day 0 and 3 in both protocols. Usage of HES 450 and DMEM results in low cell number after 3 days therefore no $\mathrm{CD}$ phenotyping was performed.

\section{Post-thaw viability}

Directly after thawing, we recorded approximately $85 \%$ cell viability with no observed difference between the different protocols and cryoprotectant-solutions (Figure 2A-B). However, viability of cells directly after thawing cannot represent reliable criteria for estimation of cryopreservation efficacy. After cultivation for 3 days, a considerable decrease in viability for some solutions was observed (Figure 2C-D). This post-thaw decrease in cell viability is known to be related to apoptotic and necrotic processes which occur within first 24 hours and are not evident immediately after thawing [16,58,59]. On day 3 after thawing, DMSO concentrations under 4\% are associated with reduced MSC viability (Figure 2D). The solution of $8 \%$ DMSO / $2 \%$ HES 450 shows on average of all protocols the highest viability compared to all
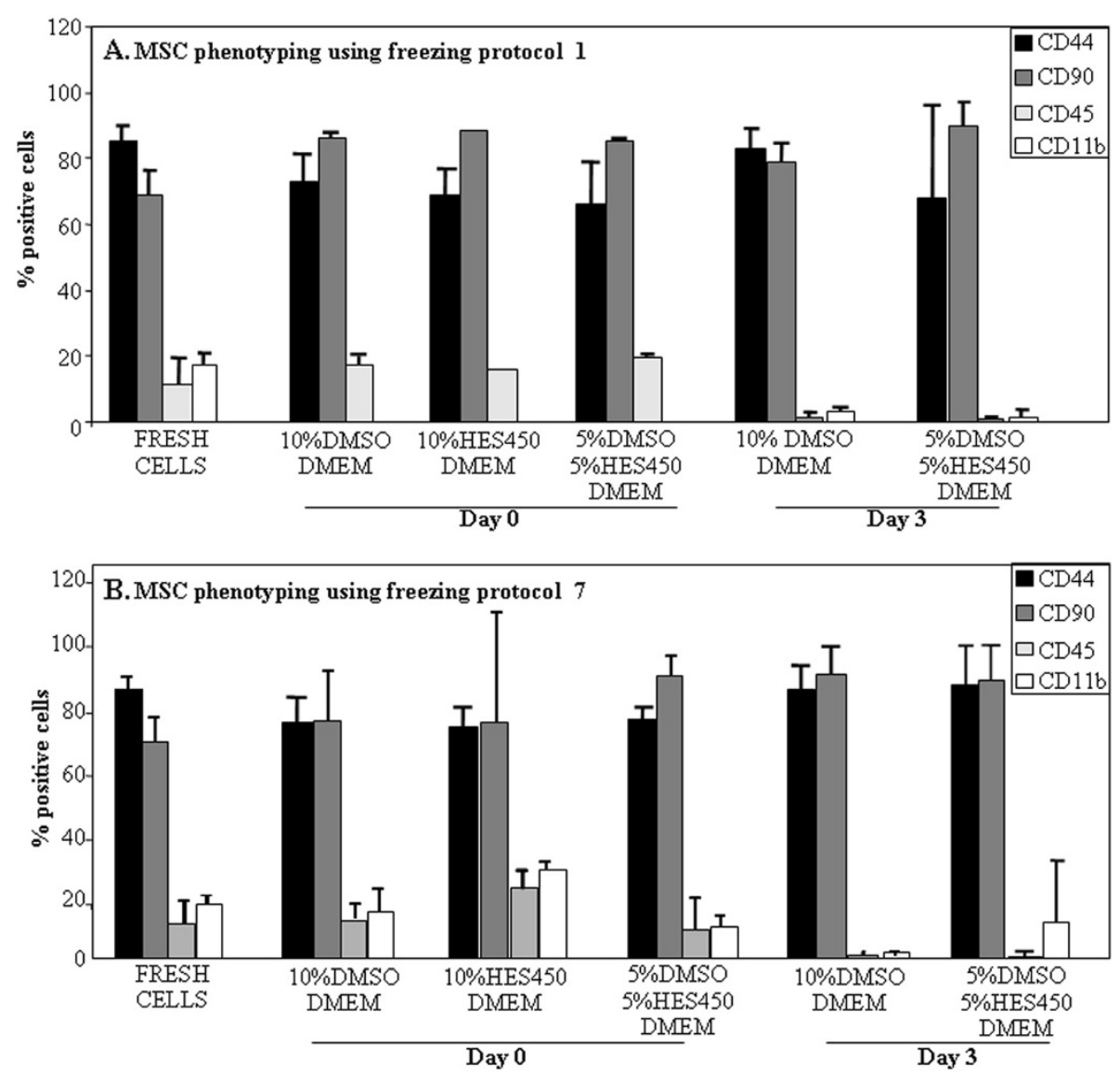

Figure 1 MSC phenotyping. Level of CD-expression in MSCs cryopreserved in different solutions directly after thawing (day 0) and after 3 days with protocol 1 (A) and protocol 7 (B). 

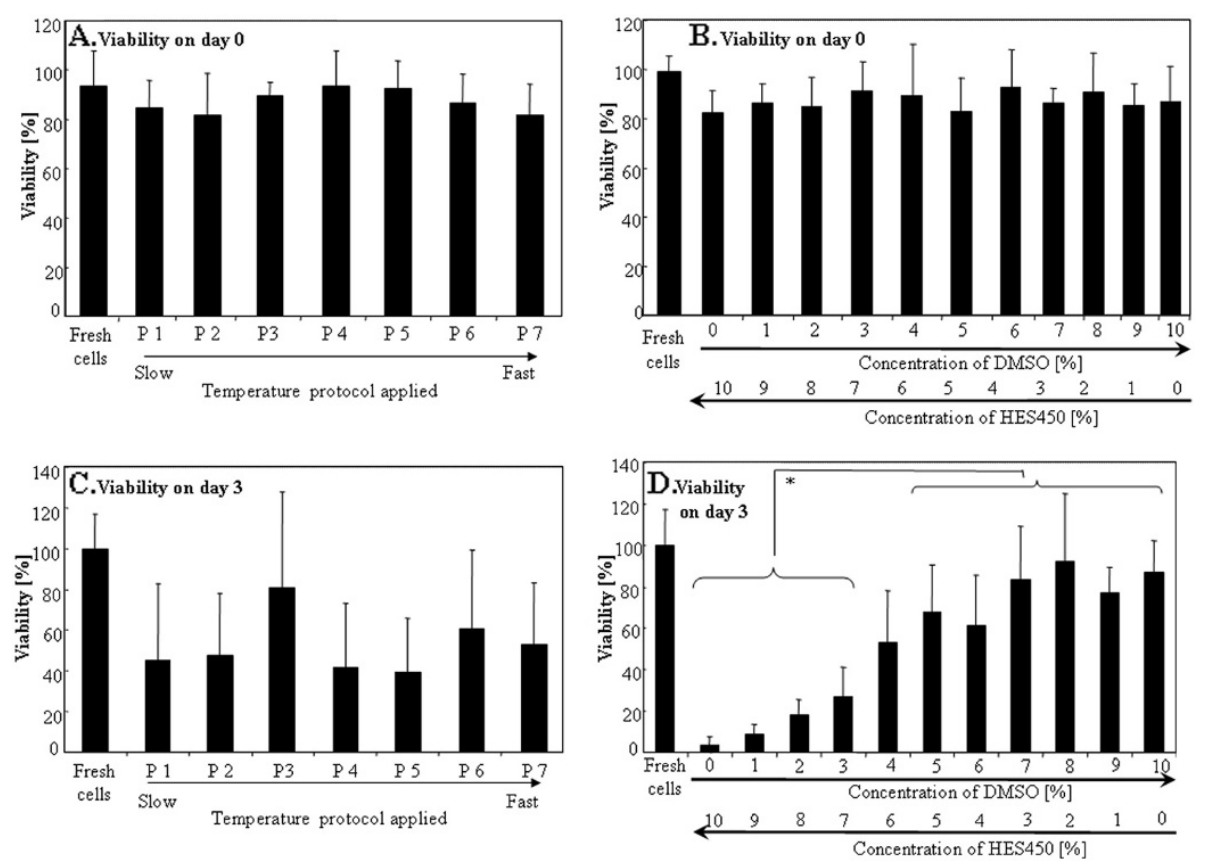

Figure 2 The effect of cryopreservation on MSC viability immediately after thawing and after 3 days at various HES/DMSO combinations and freezing rates. Viability of MSCs after cryopreservation with either different freezing rates $(\mathbf{A}, \mathbf{C})$ or different concentrations of DMSO and HES 450 (B,D) measured directly after thawing (A, B) and after 3 days by MTT (C, D).

solutions with $5 \%$ and less DMSO. Reliance on HES alone (10\% HES 450) is associated with low cell viability. MSC viability was maintained at 14 days (Figure 3B) showing that proliferation activity is not affected by prolonged culture (Additional file 2 Figure S2).

HES with the same molar substitution (0.7) but different molecular weight distributions were investigated in order to determine the relation between size of HES and its cryoprotective capacity. We used the cooling protocols 1, 5, and 6 (Table 1) which were chosen as the protocols with the most different parameters. No difference in cell viability at day 0 was observed between the solutions and protocols (data not shown). HES solutions in DMEM and FCS showed less cell viability at day 3 postthawed compared to DMSO controls (Figure 4A).

As a trend, higher HES molecular weight seems to sustain cell viability (with notable exception for protocol 5) but only in FCS not in DMEM (Figure 4A and B).

\section{Post-thaw differentiation capacity}

Thawed MSC retain their capacity to differentiate toward osteoblasts, adipocytes and chondrocytes. Qualitative assessment of the osteogenic, adipogenic and chondrogenic differentiation of MSC shows no difference in effect between the different cryosolutions (Additional file 3 Figure S1), but we only pursued osteogenic capacity in greater detail.
ALP activity is lower at 'high' (>5\%) levels of DMSO compared to solutions with a higher HES 450 content (Figure 3, C and Additional file 4 Figure S3).

No differences could be observed between HES of different molecular weights and there was no effect attributable to concurrent use of either serum or DMEM (Figure 4c).

\section{Post-thaw phenotyping}

CD90, CD44, CD45 and CD11b expression were measured in samples cryopreserved using protocol 3 and 6, in three different cryosolutions: $10 \%$ DMSO + medium, $10 \%$ HES $450+$ medium and 5\% DMSO/5\% HES $450+$ medium. CDs were measured directly after thawing and 3 days later and compared to non-cryopreserved MSC (Figure 1).

As expected, both MSCs after cryopreservation and noncryopreserved MSCs have low expression of hematopoietic stem cell markers CD11b and CD45 and high expression of mesenchymal-associated marker CD90 and CD44 [56,57]. No differences in $\mathrm{CD}$ expression were observed between day 0 and 3 in both protocols. Cryopreservation did lead to a further reduction of hematopoetic makers CD11b and CD45. Usage of HES 450 and DMEM results in such low cell number after 3 days that no $C D$ phenotyping was possible. 


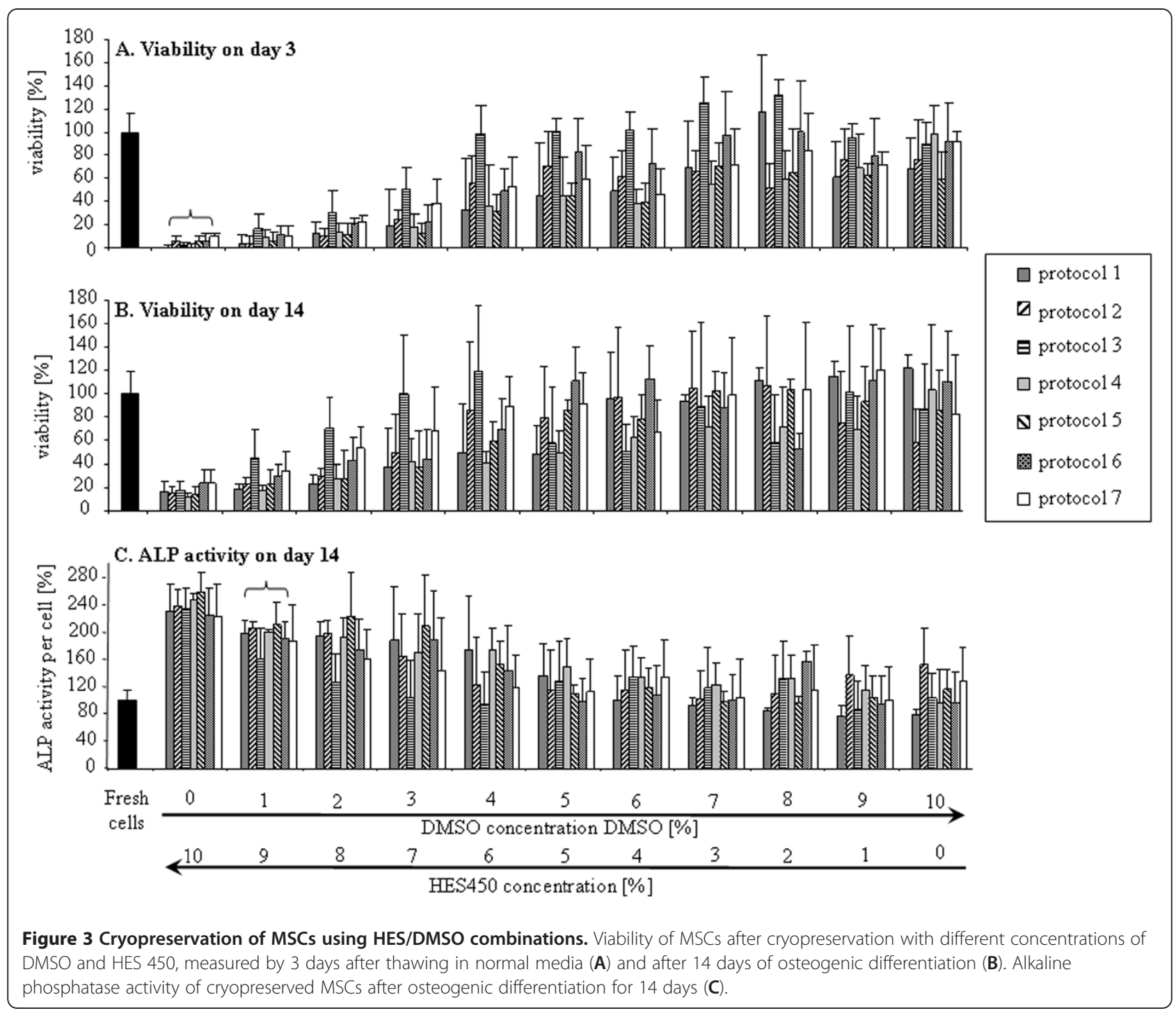

\section{Discussion}

It is not uncommon to analyze cell viability directly after thawing [47,48,60-62], however our results clearly show that this is an inaccurate measure of cryopreservation effects in rat MSC, since the different effects of various cryosolutions tested were only observable 3 days after thawing and beyond. Cryopreservation associated cell death is known to occur from $6 \mathrm{~h}$ after thawing and beyond [63-66]. We investigated different cooling protocols and found a constant cooling rate of $1^{\circ} \mathrm{C}$ per min until $-30^{\circ} \mathrm{C}$ followed by $5^{\circ} \mathrm{C}$ per min until $-80^{\circ} \mathrm{C}$ and protocols with a fast cooling rate (protocols $1 \& 6$ ) are equally suitable considering cell viability and recovery in the cryopreservation of rat MSCs. However, the choice of protocol seems to have a rather marginal effect on post-thaw viability, with little difference to a 'straight freeze' approach (protocols 6) that saves considerable time and effort. Survival rates were in the range of previous reports and MSC phenotypes were not affected by cryopreservation. It could be argued that protocols 1-3 are essential 'the same' with regards to the precooling rate of hypothetical importance, i.e., the one that governs the biophysical response of the cells being cooled. Indeed, we observe no difference between these protocols. However, since the different protocols are in practical use we have maintained their differentiated profile for reference.

\section{DMSO reduction using alternative cryoprotectants}

As discussed above and previously [43], the use of DMSO has several disadvantages. However, based on these results in rat MSC, a total substitution of DMSO with HES is not advisable if cell viability is a key indicator. Upon reducing DMSO concentration below $4 \%$ an observed decrease in cell viability can be measured, probably because of ice crystal growth in the relatively 


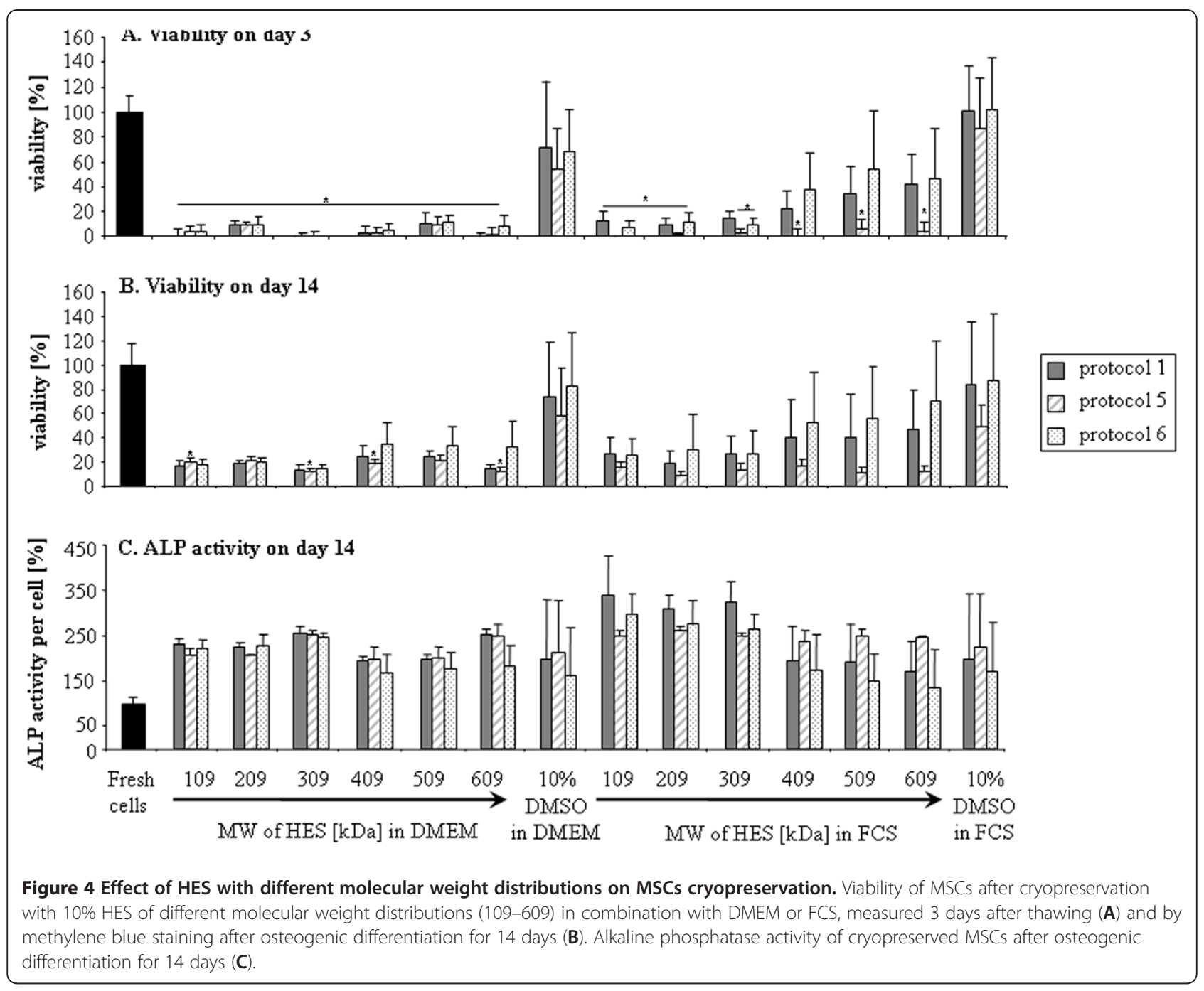

large cell body of the MSC and reduced osmotic exchange of water against DMSO during the relatively short incubation time of the cells in DMSO.

However, we could observe a slight reduction of osteogenic capacity related to higher DMSO concentrations. It is known that oxidative stress induces differentiation [67], which also occurs during freezing [68]. A badly designed freezing protocol might induce differentiation impacting on the quality of the stem cells.

If these or other drawbacks of DMSO are a factor, our results show that a partial replacement of DMSO with HES is certainly possible. Studies using a $6 \%$ HES $+5 \%$ DMSO solution usually show superior cryopreservation in comparison to $10 \%$ DMSO [43]. Regarding the 'optimum' between MSC survival and osteogenic differentiation one can conclude that while lowest DMSO concentration are slightly better for differentiation for practical tissue engineering purposes a DMSO concentration of $5 \%$ or slightly higher should be preferable.

\section{Molecular weight of HES}

In previous cryopreservation studies different MW of HES ranging from 150 to $450 \mathrm{kDa}$ were used but not compared, making it difficult to know if there are differences between the variable HES solutions $[33,69]$

For the first time we compared the effects of HES ranging from 109 to $609 \mathrm{kDa}$ with a similar hydroxyl substitution rate on viability and osteogenic differentiation. The cryopreservation with HES of different molecular weights had no effect on survival and differentiation of MSCs.

\section{Conclusion}

1. The study confirms that, for rat MSC, cryopreservation effects need to be assessed some time after, rather than immediately after thawing.

2. MSCs cryopreserved with HES maintain their characteristic cell surface marker expression as well 
as the osteogenic, adipogenic and chondrogenic differentiation potential.

3. There are no major changes in the expression of surface proteins identifying MSC, proliferation capacity and osteogenic differentiation in MSC frozen with 5\% DMSO/ 5\% HES.

4. HES alone does not provide sufficient cryoprotection for rat MSCs, but provides good cryoprotection in combination with DMSO, permitting the DMSO content to be reduced to $5 \%$. There are indications that such a combination would seem useful not just for the clinical disadvantages of DMSO but also based on a tendency for reduced osteogenic differentiation capacity in rat MSC cryopreserved with high DMSO concentration.

5. HES molecular weight appears to play only a minor role in its capacity to act as a cryopreservation solution for MSC.

6. The use of a 'straight freeze' protocol is no less effective in maintaining post-thaw viability of MSC compared to controlled rate freezing methods.

As a simplified summary, a 5\% DMSO / 5\% HES solution cryopreservation solution using a 'straight freeze' approach can be recommended as 'optimal' for 'normal' rat MSC cryopreservation.

\section{Additional file}

Additional file 1: Figure S4. Freezing curves of the machine cryopreservation protocols. The curves for the machine based freezing rates were recorded by the machine and summarized here for the protocols 1-6. The curves show just small variations during the heat release phase between 0 and $-10^{\circ} \mathrm{C}$.

Additional file 2: Figure S2. Cellular Morphology of cryopreserved rat MSC. Morphology of cryopreserved rat MSC after 14 days in culture.

Additional file 3: Figure S1. Differentiation capacity of rat MSCs after cryopreservation. Qualitative ALP-staining of MSCs after 14 days osteogenic differentiation. Magnification 20X (A). Oil red O staining of MSCs after 14 days in adipogenic differentiation medium. Magnification 40X (B). Chondrogenic staining of differentiated MSCs cells after 14 days. Magnification 20X (C).

Additional file 4: Figure S3. Morphology of cryopreserved rat MSC during osteogenesis. Cellular morphology of cryopreserved rat MSC after 14 days in osteogenic differentiation medium.

\section{Competing interests}

This work was supported in part by Serumwerke Bernburg a manufacturer of HES.

\section{Authors' contributions}

MS carried out the bulk of the experiments, VF contributed to some phenotyping experiments and sections of the manuscript. YN conducted the phenotyping and chondrocyte experiments, consolidated data and provided the first draft of the manuscript. AS planned the experiments, secured the funding and revised the manuscript. All authors read and approved the final manuscript.

\section{Acknowledgements}

Thanks goes to Dr. Sebastian Sethe for advice on data interpretation and manuscript revision.

Received: 10 April 2012 Accepted: 31 July 2012

Published: 13 August 2012

\section{References}

1. Abdallah BM, Kassem M: Human mesenchymal stem cells: from basic biology to clinical applications. Gene Ther 2008, 15:109-116.

2. Chamberlain G, Fox J, Ashton B, Middleton J: Concise review: mesenchymal stem cells: their phenotype, differentiation capacity, immunological features, and potential for homing. Stem Cells 2007, 25:2739-2749

3. Reyes M, Verfaillie CM: Characterization of multipotent adult progenitor cells, a subpopulation of mesenchymal stem cells. Ann N Y Acad Sci 2001, 938:231-233. discussion 233-235.

4. Woodbury D, Schwarz EJ, Prockop DJ, Black IB: Adult rat and human bone marrow stromal cells differentiate into neurons. J Neurosci Res 2000, 61:364-370.

5. Pittenger MF, Mackay AM, Beck SC, Jaiswal RK, Douglas R, Mosca JD, Moorman MA, Simonetti DW, Craig S, Marshak DR: Multilineage potential of adult human mesenchymal stem cells. Science 1999, 284:143-147.

6. Wakitani S, Saito T, Caplan Al: Myogenic cells derived from rat bone marrow mesenchymal stem cells exposed to 5-azacytidine. Muscle Nerve 1995, 18:1417-1426.

7. Qi W, Ding D, Salvi RJ: Cytotoxic effects of dimethyl sulphoxide (DMSO) on cochlear organotypic cultures. Hear Res 2008, 236:52-60.

8. Wang X, Hua TC, Sun DW, Liu B, Yang G, Cao Y: Cryopreservation of tissue-engineered dermal replacement in Me2SO: Toxicity study and effects of concentration and cooling rates on cell viability. Cryobiology 2007, 55:60-65.

9. Katkov II, Kim MS, Bajpai R, Altman YS, Mercola M, Loring JF, Terskikh AV, Snyder EY, Levine F: Cryopreservation by slow cooling with DMSO diminished production of Oct-4 pluripotency marker in human embryonic stem cells. Cryobiology 2006, 53:194-205.

10. Reubinoff BE, Pera MF, Vajta G, Trounson AO: Effective cryopreservation of human embryonic stem cells by the open pulled straw vitrification method. Hum Reprod 2001, 16:2187-2194.

11. Haack-Sorensen M, Bindslev L, Mortensen S, Friis T, Kastrup J: The influence of freezing and storage on the characteristics and functions of human mesenchymal stromal cells isolated for clinical use. Cytotherapy 2007, 9:328-337.

12. Lee RH, Kim B, Choi I, Kim H, Choi HS, Suh K, Bae YC, Jung JS: Characterization and expression analysis of mesenchymal stem cells from human bone marrow and adipose tissue. Cell Physiol Biochem 2004 14:311-324

13. Hunt CJ: Cryopreservation of Human Stem Cells for Clinical Application: A Review. Transfus Med Hemother 2011, 38:107-123.

14. Djuwantono T, Wirakusumah FF, Achmad TH, Sandra F, Halim D, Faried A: A comparison of cryopreservation methods: Slow-cooling vs. rapid-cooling based on cell viability, oxidative stress, apoptosis, and CD34+ enumeration of human umbilical cord blood mononucleated cells. BMC Res Notes 2011, 4:371.

15. Bruder SP, Jaiswal N, Haynesworth SE: Growth kinetics, self-renewal, and the osteogenic potential of purified human mesenchymal stem cells during extensive subcultivation and following cryopreservation. I Cell Biochem 1997, 64:278-294.

16. Kotobuki N, Hirose M, Machida H, Katou Y, Muraki K, Takakura Y, Ohgushi H: Viability and osteogenic potential of cryopreserved human bone marrow-derived mesenchymal cells. Tissue Eng 2005, 11:663-673.

17. Perry BC, Zhou D, Wu X, Yang FC, Byers MA, Chu TM, Hockema JJ, Woods EJ, Goebel WS: Collection, cryopreservation, and characterization of human dental pulp-derived mesenchymal stem cells for banking and clinical use. Tissue Eng Part C Methods 2008, 14:149-156.

18. Rust PA, Costas C, Cannon SR, Briggs TW, Blunn GW: Characterisation of cryopreserved cells freshly isolated from human bone marrow. Cryo Letters 2006, 27:17-28.

19. Liu G, Zhou H, Li Y, Li G, Cui L, Liu W, Cao Y: Evaluation of the viability and osteogenic differentiation of cryopreserved human adipose-derived stem cells. Cryobiology 2008, 57:18-24. 
20. Bhakta G, Lee KH, Magalhaes R, Wen F, Gouk SS, Hutmacher DW, Kuleshova $\mathrm{LL}$ : Cryopreservation of alginate-fibrin beads involving bone marrow derived mesenchymal stromal cells by vitrification. Biomaterials 2009, 30:336-343.

21. Moon JH, Kwak SS, Park G, Jung HY, Yoon BS, Park J, Ryu KS, Choi SC, Maeng I, Kim B, et al: Isolation and characterization of multipotent human keloid-derived mesenchymal-like stem cells. Stem Cells Dev 2008, 17:713-724.

22. Goh BC, Thirumala S, Kilroy G, Devireddy RV, Gimble JM: Cryopreservation characteristics of adipose-derived stem cells: maintenance of differentiation potential and viability. J Tissue Eng Regen Med 2007 1(4):322-324.

23. Lee MW, Choi J, Yang MS, Moon YJ, Park JS, Kim HC, Kim YJ: Mesenchymal stem cells from cryopreserved human umbilical cord blood. Biochem Biophys Res Commun 2004, 320:273-278.

24. Higman MA, Port JD, Beauchamp NJ Jr, Chen AR: Reversible leukoencephalopathy associated with re-infusion of DMSO preserved stem cells. Bone Marrow Transplant 2000, 26:797-800.

25. Hequet O, Dumontet C, El Jaafari-Corbin A, Salles G, Espinouse D, Arnaud P, Thieblemont C, Bouafia F, Coiffier B: Epileptic seizures after autologous peripheral blood progenitor infusion in a patient treated with high-dose chemotherapy for myeloma. Bone Marrow Transplant 2002, 29:544.

26. Gomez S, Nagler A, Naparstek E, Slavin S: Transient elevation of serum lactic dehydrogenase following autologous bone marrow transplantation. Bone Marrow Transplant 1991, 7:487-488

27. Penninckx F, Cheng N, Kerremans R, Van Damme B, De Loecker W: The effects of different concentrations of glycerol and dimethylsulfoxide on the metabolic activities of kidney slices. Cryobiology 1983, 20:51-60.

28. Thirumala S, Gimble JM, Devireddy RV: Evaluation of methylcellulose and dimethyl sulfoxide as the cryoprotectants in a serum-free freezing media for cryopreservation of adipose-derived adult stem cells. Stem Cells Dev 2010, 19:513-522.

29. Thirumala S, Gimble JM, Devireddy RV: Cryopreservation of stromal vascular fraction of adipose tissue in a serum-free freezing medium. $\lrcorner$ Tissue Eng Regen Med 2010, 4:224-232.

30. Liu Y, Xu X, Ma XH, Liu J, Cui ZF: Effect of various freezing solutions on cryopreservation of mesenchymal stem cells from different animal species. Cryo Letters 2011, 32:425-435.

31. Allen ED, Weatherbee L, Spencer HH, Lindenauer SM, Permoad PA: Large unit red cell cryopreservation with hydroxyethyl starch. Cryobiology 1976, 13:500-506.

32. Pasch J, Schiefer A, Heschel I, Dimoudis N, Rau G: Variation of the HES concentration for the cryopreservation of keratinocytes in suspensions and in monolayers. Cryobiology 2000, 41:89-96.

33. Sudo K, Asoh S, Ohsawa I, Ozaki D, Yamagata K, Ito H, Ohta S: The anti-cel death FNK protein protects cells from death induced by freezing and thawing. Biochem Biophys Res Commun 2005, 330:850-856.

34. Celluzzi CM, Welbon C: A simple cryopreservation method for dendritic cells and cells used in their derivation and functional assessment. Transfusion 2003, 43:488-494.

35. Ashwood-Smith MJ, Warby C, Connor KW, Becker G: Low-temperature preservation of mammalian cells in tissue culture with polyvinylpyrrolidone (PVP), dextrans, and hydroxyethyl starch (HES). Cryobiology 1972, 9:441-449.

36. Sputtek A, Jetter S, Hummel K, Kuhnl P: Cryopreservation of peripheral blood progenitor cells: characteristics of suitable techniques. Beitr Infusionsther Transfusionsmed 1997, 34:79-83.

37. Horn EP, Sputtek A, Standl T, Rudolf B, Kuhnl P, Schulte am Esch J: Transfusion of autologous, hydroxyethyl starch-cryopreserved red blood cells. Anesth Analg 1997, 85:739-745.

38. Lionetti FJ, Hunt SM: Cryopreservation of human red cells in liquid nitrogen with hydroxyethyl starch. Cryobiology 1975, 12:110-118

39. Persidsky MD, Ellett MH: Hydroxyethyl starch as a cryopreservative for nucleated mammalian cells. Cryobiology 1971, 8:586-588.

40. Stiff PJ, Koester AR, Weidner MK, Dvorak K, Fisher Rl: Autologous bone marrow transplantation using unfractionated cells cryopreserved in dimethylsulfoxide and hydroxyethyl starch without controlled-rate freezing. Blood 1987, 70:974-978.

41. Boldt J: Modern rapidly degradable hydroxyethyl starches: current concepts. Anesth Analg 2009, 108:1574-1582.
42. Westphal M, Lamszus K: Other experimental therapies for glioma. Recent Results Cancer Res 2009, 171:155-164.

43. Stolzing A, Naaldijk Y, Fedorova V, Sethe S: Hydroxyethylstarch in cryopreservation - Mechanisms, benefits and problems. Transfus Apher Sci 2012, 46:137-147.

44. Rodrigues JP, Paraguassu-Braga FH, Carvalho L, Abdelhay E, Bouzas LF, Porto LC: Evaluation of trehalose and sucrose as cryoprotectants for hematopoietic stem cells of umbilical cord blood. Cryobiology 2008, 56:144-151.

45. Rowley SD, Feng Z, Chen L, Holmberg L, Heimfeld S, MacLeod B, Bensinger WI: A randomized phase III clinical trial of autologous blood stem cell transplantation comparing cryopreservation using dimethylsulfoxide vs dimethylsulfoxide with hydroxyethylstarch. Bone Marrow Transplant 2003, 31:1043-1051.

46. Pasch J, Schiefer A, Heschel I, Rau G: Cryopreservation of keratinocytes in a monolayer. Cryobiology 1999, 39:158-168.

47. Teasdale B, Sieber VK, Riches DJ, Nanchahal J: Cryopreservation of cultured dermal fibroblast impregnated collagen gels. Burns 1993, 19:406-410.

48. Kearney JN: Cryopreservation of cultured skin cells. Burns 1991 17:380-383.

49. Ji L, de Pablo JJ, Palecek SP: Cryopreservation of adherent human embryonic stem cells. Biotechnol Bioeng 2004, 88:299-312.

50. Stiff PJ, Murgo AJ, Zaroulis CG, DeRisi MF, Clarkson BD: Unfractionated human marrow cell cryopreservation using dimethylsulfoxide and hydroxyethyl starch. Cryobiology 1983, 20:17-24.

51. Rowley SD, Anderson GL: Effect of DMSO exposure without cryopreservation on hematopoietic progenitor cells. Bone Marrow Transplant 1993, 11:389-393.

52. Leibo SP, Mazur P: The role of cooling rates in low-temperature preservation. Cryobiology 1971, 8:447-452.

53. Franks F, Mathias SF, Galfre P, Webster SD, Brown D: Ice nucleation and freezing in undercooled cells. Cryobiology 1983, 20:298-309.

54. Mazur P: Freezing of living cells: mechanisms and implications. Am J Physiol 1984, 247:C125-C142.

55. Kandra D, Devireddy RV: Numerical Simulation of Local Temperature Distortions During Ice Nucleation of Cells in Suspension. Int J Heat Mass Transf 2008, 51:5655-5661.

56. Martinello T, Bronzini I, Maccatrozzo L, Mollo A, Sampaolesi M, Mascarello F, Decaminada M, Patruno M: Canine adipose-derived-mesenchymal stem cells do not lose stem features after a long-term cryopreservation. Res Vet Sci 2011, 91:18-24

57. Martinello T, Bronzini I, Maccatrozzo L, lacopetti I, Sampaolesi M, Mascarello F, Patruno M: Cryopreservation does not affect the stem characteristics of multipotent cells isolated from equine peripheral blood. Tissue Eng Part C Methods 2010, 16:771-781.

58. Heng BC, Ye CP, Liu H, Toh WS, Rufaihah AJ, Yang Z, Bay BH, Ge Z, Ouyang $H W$, Lee $E H$, et al: Loss of viability during freeze-thaw of intact and adherent human embryonic stem cells with conventional slow-cooling protocols is predominantly due to apoptosis rather than cellular necrosis. J Biomed Sci 2006, 13:433-445.

59. Heng BC: Effect of Rho-associated kinase (ROCK) inhibitor Y-27632 on the post-thaw viability of cryopreserved human bone marrow-derived mesenchymal stem cells. Tissue Cell 2009, 41:376-380.

60. Carvalho KA, Cury CC, Oliveira L, Cattaned RI, Malvezzi M, Francisco JC Pachalok A, Olandoski M, Faria-Neto JR, Guarita-Souza LC: Evaluation of bone marrow mesenchymal stem cell standard cryopreservation procedure efficiency. Transplant Proc 2008, 40:839-841.

61. Ock SA, Rho GJ: Effect of dimethyl sulfoxide (DMSO) on cryopreservation of porcine mesenchymal stem cells (pMSCs). Cell Transplant 2011, 20:1231-1239.

62. Li H, Yan F, Lei L, Li Y, Xiao Y: Application of autologous cryopreserved bone marrow mesenchymal stem cells for periodontal regeneration in dogs. Cells Tissues Organs 2009, 190:94-101.

63. Borderie VM, Lopez M, Lombet A, Carvajal-Gonzalez S, Cywiner C, Laroche L: Cryopreservation and culture of human corneal keratocytes. Invest Ophthalmol Vis Sci 1998, 39:1511-1519.

64. Baust JM, Van B, Baust JG: Cell viability improves following inhibition of cryopreservation-induced apoptosis. In Vitro Cell Dev Biol Anim 2000, 36:262-270.

65. Baust JM: Molecular Mechanism of Cellular Demise Associated with Cryopreservation Failure. Cell Preservation Technology 2002, 1:17-31. 
66. Baust JMV MJ, Snyder KK, Van Buskirk RG, Baust JG: Activation of Mitochondrial-Associated Apoptosis Contributes to Cryopreservation Failure. Cell Preservation Technology 2007, 5:155-164.

67. Hronik-Tupaj M, Rice WL, Cronin-Golomb M, Kaplan DL, Georgakoudi I: Osteoblastic differentiation and stress response of human mesenchymal stem cells exposed to alternating current electric fields. Biomed Eng Online 2011, 10:9.

68. Han DW, Kim HH, Lee MH, Baek HS, Lee KY, Hyon SH, Park JC: Protection of osteoblastic cells from freeze/thaw cycle-induced oxidative stress by green tea polyphenol. Biotechnol Lett 2005 27:655-660.

69. Luo K, Wu G, Wang Q, Sun Y, Liu H: Effect of dimethylsulfoxide and hydroxyethyl starch in the preservation of fractionated human marrow cells. Cryobiology 1994, 31:349-354

doi:10.1186/1472-6750-12-49

Cite this article as: Naaldijk et al.: Effect of different freezing rates during cryopreservation of rat mesenchymal stem cells using combinations of hydroxyethyl starch and dimethylsulfoxide. BMC Biotechnology 2012

\section{Submit your next manuscript to BioMed Central and take full advantage of:}

- Convenient online submission

- Thorough peer review

- No space constraints or color figure charges

- Immediate publication on acceptance

- Inclusion in PubMed, CAS, Scopus and Google Scholar

- Research which is freely available for redistribution 